\title{
Aboveground environment type, soil nutrient content and arbuscular mycorrhizal fungi explain establishment success of Centaurea jacea on ex-arable land and in late-successional grasslands
}

\author{
René Eschen • Heinz Müller-Schärer • \\ Urs Schaffner
}

Received: 9 July 2008 / Accepted: 13 January 2009 / Published online: 3 February 2009

(C) Springer Science + Business Media B.V. 2009

\begin{abstract}
We studied the relative importance of the aboveground and belowground environment for survival and growth of emerged seedlings of Centaurea jacea to better understand the general difficulty of establishing late-successional species at restoration sites on ex-arable land. Potted seedlings growing on soil from six late-successional grasslands and from six ex-arable (restoration) sites were reciprocally exchanged, and survival and relative growth rate of the seedlings monitored. In addition, we assessed aboveground herbivory and colonization of roots by arbuscular myccorhizal fungi of all plants, as well as nutrient availability, and microbial biomass and community composition using PLFA techniques in all twelve soils. Seedling survival was higher in
\end{abstract}

Responsible Editor: Wim van der Putten.

R. Eschen $(\bowtie)$

School of Biological Sciences, Royal Holloway,

University of London,

Egham TW20 0EX, United Kingdom

e-mail: rene.eschen@rhul.ac.uk

R. Eschen $\cdot$ U. Schaffner

CABI Europe-Switzerland,

1 Rue des Grillons,

Delémont CH-2800, Switzerland

R. Eschen $\cdot$ H. Müller-Schärer

Department of Biology, Unit Ecology and Evolution,

University of Fribourg,

Fribourg CH-1700, Switzerland restoration habitat and soil than in grassland habitat and soil, but growth did not differ between the aboveground and belowground environment types. Shoot growth rate was initially correlated with soil nutrient content, and later in the experiment with mycorrhizal colonization levels. Our results indicate that arbuscular mycorhizal fungi may be important for the successful establishment of $C$. jacea and that abiotic soil factors, like $\mathrm{K}$ availability and N:P ratio, can promote mycorrhizal colonization. Hence, the belowground environment should be considered when selecting sites for restoring species-rich grasslands.

Keywords Aboveground and belowground environments · AM fungi . Centaurea jacea . Grassland creation · Phospholipid fatty acid (PFLA) analysis $\cdot$ Soil transplant study

\section{Introduction}

The successful establishment of sown late-successional plant species on grassland restoration sites on ex-arable land is often disappointing (Kleijn and Sutherland 2003). This has been attributed to a number of abiotic and biotic factors in the aboveground and belowground environment that affect survival and growth of latesuccessional grassland plant species, including high availability of soil nutrients such as $\mathrm{P}, \mathrm{K}$ and inorganic N (McLendon and Redente 1992; Marrs 1993), 
arbuscular mycorrhizal fungi (AM fungi; Van der Heijden 2004), inter-specific competition (Tilman 1993; Hansson and Fogelfors 1998) and aboveground herbivory (Edwards and Crawley 1999). While some factors of the aboveground and belowground environment have been jointly investigated (Brown and Gange 1989; Schadler et al. 2004), there is a paucity of studies considering all factors at the same time and hence, the relative importance of aboveground and belowground factors for seedling survival and growth are not well understood. As restoration sites on exarable fields differ from late-successional grasslands both in terms of the aboveground and the belowground environment (Walker et al. 2004), the two ecosystem compartments and their characteristics should be jointly considered when studying secondary succession in restoration programmes. A better understanding of the relative importance of aboveground and belowground factors affecting seedling survival and growth of sown late-successional plant species could improve the selection of potentially suitable sites for the creation of species-rich grassland habitat.

The overall effect of the aboveground and belowground environment on seedling recruitment and vegetation development may depend to a large extent on how these ecosystem compartments affect one another (Wardle 2002). Therefore, experiments are necessary to disentangle their relative importance for the survival and the establishment of emerged seedlings of late-successional plant species. Moreover, since the outcome of studies assessing the effects of aboveground and belowground factors on plant survival and growth may vary depending on the initial characteristics of the study system, it is important to carry out such experiments in a range of natural habitats and soils, thereby incorporating ecosystem complexity in the experimental design (Read 2002). While many studies that aimed to assess the impact of various components of the biotic belowground environment on plant growth were done by standardizing either the aboveground or the belowground environment among the treatments (e.g. Van der Heijden et al. 1998; Klironomos 2002; De Deyn et al. 2003; Wardle et al. 2005), only few studies incorporated the natural variability of ecosystem components (e.g. Brown and Gange 1989; Gange and West 1994; Gange et al. 2002; Kardol et al. 2006, 2008).

We carried out a reciprocal transplant experiment with pots containing soil from late-successional grasslands or restoration sites among the sites where the soil originated from. We investigated the relative effect of the aboveground environment ("habitat") and that of the belowground environment of restoration sites and of late-successional grasslands on growth and survival of emerged seedlings of the model species Centaurea jacea L., a widespread perennial, often predominant plant species of latesuccessional vegetation stages that has a wide ecological amplitude (Ellenberg 1974). This species is commonly included in seed mixtures for the creation of grassland habitats on restoration sites (Bosshard 1999). We specifically tested whether survival and growth of $C$. jacea under field conditions are affected by habitat type (restoration vs. latesuccessional grassland) or by belowground environment type. In general we expected better survival and growth of $C$. jacea in soils of the late-successional grasslands, mainly due to the higher organic matter content and microbial biomass than in the belowground environment of the restoration sites. Both measures are often higher in later stages of grassland succession (e.g. Kindscher and Tieszen 1998; Bardgett and McAlister 1999), and hence reflect the species' natural habitat. In addition, we assessed correlations between survival and growth of $C$. jacea and various belowground environment and habitat parameters to identify those factors that best explain establishment of C. jacea across the two belowground environment and habitat types.

\section{Methods}

Experimental setup

Soil was taken from six restoration sites and six latesuccessional grasslands in the Swiss Jura (Table 1). The late-successional grasslands, all with well-developed Mesobromion or Arrhenaterion vegetation types, were mown once or twice a year after mid-June and not fertilized; no previous management of the latesuccessional grasslands other than regular mowing was known. By contrast, all restoration sites had a long history of intensive agriculture prior to restoration management. The restoration sites had been under restoration management schemes for two to 6 years prior to the experiment; no fertilizer or pesticides had been applied since and the sites were mown once a 
Table 1 Summary of characteristics of soil chemistry and microbial community of individual soil origins and belowground environment types. Averages (with standard error in brackets) in bold differ significantly between the two belowground environment types

\begin{tabular}{|c|c|c|c|c|c|c|c|c|c|c|c|}
\hline Site & $\begin{array}{l}\mathrm{N}-\mathrm{NH}_{4}{ }^{+} \\
\text {ppm }\end{array}$ & $\begin{array}{l}\mathrm{N}-\mathrm{NO}_{3}{ }^{-} \\
\mathrm{ppm}\end{array}$ & P ppm & $\mathrm{N}: \mathrm{P}$ & $\mathrm{K}$ ppm & $\% \mathrm{OM}$ & $\%$ Water & $\begin{array}{l}\text { Fungal PLFAs } \\
\mathrm{nmol} \mathrm{g} \mathrm{soil}^{-1}\end{array}$ & $\begin{array}{l}\text { Bacterial } \\
\text { PLFAs nmol } \\
\text { g soil }^{-1}\end{array}$ & $\begin{array}{l}\text { AM fungal } \\
\text { NLFAs nmol } \\
\text { g soil }\end{array}$ & $\begin{array}{l}\text { Fungal-to- } \\
\text { bacterial } \\
\text { ratio }\end{array}$ \\
\hline \multicolumn{12}{|l|}{ Grassland } \\
\hline Corban & 16.0 & 50.7 & 19.6 & 3.40 & 172.4 & 15.3 & 22.0 & 3.4 & 74.5 & 20.3 & 0.05 \\
\hline Courchapoix & 9.2 & 93.7 & 59.9 & 1.72 & 278.8 & 20.0 & 31.6 & 3.5 & 83.2 & 23.7 & 0.04 \\
\hline Movelier & 7.6 & 75.0 & 19.0 & 4.35 & 138.0 & 15.0 & 22.8 & 8.2 & 91.2 & 8.8 & 0.09 \\
\hline Soyhières-O & 8.3 & 38.7 & 14.4 & 3.26 & 159.2 & 12.3 & 15.3 & 4.6 & 101.0 & 19.6 & 0.05 \\
\hline Soyhières-W & 15.5 & 117.2 & 25.3 & 5.25 & 135.2 & 16.0 & 23.1 & 5.1 & 99.3 & 17.3 & 0.05 \\
\hline Vorbourg & 10.1 & 29.6 & 16.2 & 2.45 & 200.8 & 15.1 & 12.3 & 5.1 & 80.7 & 11.7 & 0.06 \\
\hline Average & $\begin{array}{l}11.1 \\
(1.5)\end{array}$ & $\begin{array}{r}67.5 \\
(13.9)\end{array}$ & $\begin{array}{l}25.7 \\
(7.0)\end{array}$ & $\begin{array}{l}3.40 \\
(0.52)\end{array}$ & $\begin{array}{l}180.7 \\
(22.0)\end{array}$ & $\begin{array}{c}15.6 \\
(1.0)\end{array}$ & $\begin{array}{l}21.2 \\
(2.8)\end{array}$ & $\begin{array}{l}5.0 \\
(0.7)\end{array}$ & $\begin{array}{c}88.3 \\
(4.3)\end{array}$ & $\begin{array}{c}16.9 \\
(2.3)\end{array}$ & $\begin{array}{l}0.06 \\
(0.01)\end{array}$ \\
\hline \multicolumn{12}{|l|}{ Restoration } \\
\hline Corban & 15.1 & 21.1 & 4.3 & 8.42 & 124.0 & 6.6 & 17.4 & 1.7 & 62.5 & 9.3 & 0.03 \\
\hline Courchapoix & 5.8 & 49.7 & 39.5 & 1.41 & 311.6 & 11.7 & 25.0 & 0.7 & 30.2 & 3.0 & 0.02 \\
\hline Courroux & 5.8 & 29.2 & 38.1 & 0.92 & 356.0 & 7.6 & 14.1 & 2.9 & 44.0 & 4.6 & 0.07 \\
\hline Courtételle & 25.9 & 37.1 & 29.8 & 2.11 & 225.6 & 13.0 & 20.6 & 2.9 & 87.2 & 4.3 & 0.03 \\
\hline Movelier & 6.5 & 28.7 & 20.5 & 1.72 & 212.0 & 12.1 & 20.9 & 4.1 & 73.5 & 16.9 & 0.06 \\
\hline Rossemaison & 6.9 & 40.7 & 31.7 & 1.50 & 258.0 & 5.9 & 14.6 & NA & NA & 7.4 & NA \\
\hline Average & $\begin{array}{l}11.0 \\
(3.3)\end{array}$ & $\begin{array}{c}34.4 \\
(4.2)\end{array}$ & $\begin{array}{l}27.3 \\
(5.4)\end{array}$ & $\begin{array}{l}2.68 \\
(1.16)\end{array}$ & $\begin{array}{l}247.9 \\
(33.2)\end{array}$ & $\begin{array}{l}9.5 \\
(1.3)\end{array}$ & $\begin{array}{l}18.8 \\
(1.7)\end{array}$ & $\begin{array}{l}2.5 \\
(0.6)\end{array}$ & $\begin{array}{l}59.5 \\
(10.2)\end{array}$ & $\begin{array}{l}7.6 \\
(2.1)\end{array}$ & $\begin{array}{l}0.04 \\
(0.01)\end{array}$ \\
\hline
\end{tabular}

year after June 15. Three of the sites had been under restoration management for a number of years prior to the start of the experiment and we were unable to retrieve what the last crops on those sites had been. On the other sites, the last crop had been wheat. Most of the sites had been sown with a standard 30-species mixture as part of the restoration management (Bosshard 1999). Vegetation cover was similar in restoration sites and late-successional grasslands $(60-80 \%$; R. Eschen, personal observation).

From each site, twelve soil cores (diameter approx. $6.5 \mathrm{~cm}$, depth $18 \mathrm{~cm}$, approximately $50 \mathrm{~cm}$ apart) were taken with as little disturbance of the surrounding vegetation and soil surface as possible. The soil was collected at least $15 \mathrm{~m}$ from the edge of each field. Soils from the 12 sites were kept separately. The soil from each site was pooled, sieved $(5 \mathrm{~mm}$ mesh size) and living plant tissues and dry litter carefully removed. Soil from each site was put into 12 pots consisting of plastic tubes $(6.5 * 18 \mathrm{~cm})$ that were closed at the bottom with a $60 \mu \mathrm{m}$ mesh (LanzAnliker AG, Rohrbach, Switzerland) to allow water to flow out, but prevent soil micro- and macroarthropods from entering. Seedlings of $C$. jacea were grown from surface-sterilized seeds, obtained from a commercial supplier, on moist filter paper in Petri dishes. Three seedlings were planted at the cotyledon stage in the centre of each pot. Pots were kept in the greenhouse for 2 weeks for establishment of the seedlings. Then, the number of seedlings was reduced to one per pot by randomly removing surplus plants. Each pot was randomly assigned to one of the twelve source sites, so that one pot of each of the 12 soils was assigned to each of the 12 sites (12 pots per site, 144 pots in total). In June 2003, pots were put into the holes where the soil was taken from, with the rim at the level of the soil surface. Slug pellets were added (Blaukorn, Pluss-Staufer AG, Oftringen Switzerland), but no measures were taken to prevent micro- and macroarthropods from entering the pots through the top of the pots.

Size of the plants was estimated as the sum of the area of all leaves, estimated for each leaf individually by multiplying the maximum length and width of the leaf, when the pots were put into the field (day 0) and 14, 28, 46 and 62 days thereafter. At days 28 and 62, the number of dead plants was counted and the area of the surviving plants damaged by herbivores was 
estimated to the nearest ten percent for each individual leaf. Average survival (in \%) was calculated for plants growing on each soil type within each site, using data from day 28 and 62 . We analyzed the results of both dates and they provided similar results. Since most of the mortality occurred during the first phase of the experiment, we present analysis of survival data of day 28. The pattern in survival of C. jacea at day 62 was similar to the pattern found at day 28. We harvested the plants after 62 days when it was observed that roots started to accumulate at the bottom of the pots. Soil was washed off the roots, and plants were divided into roots and shoots, oven-dried at $60{ }^{\circ} \mathrm{C}$ for $36 \mathrm{~h}$ and weighed. Because the increase in leaf area was reduced after day 46 , shoot relative growth rate of plants between day 0 and 46 and between day 46 and 62 was calculated separately. Relative growth rate of each individual plant between day 0 and 46 was calculated as the slope of a linear regression of log-transformed leaf area against time. Relative growth rate of each individual plant between day 46 and 62 was calculated as the difference in leaf area between the two dates divided by the number of days separating the two dates. Two plants with negative regression slopes were excluded from the analysis of relative growth rate. For each plant, herbivory was expressed as the mean area damaged per leaf (in \%).

\section{Chemical analyses}

Soil samples for chemical and PLFA analyses were taken when the soil was collected in the field and stored at $-20{ }^{\circ} \mathrm{C}$ until analysis. Samples were airdried $\left(<30^{\circ} \mathrm{C}\right)$ and sieved $(<2 \mathrm{~mm})$ before analyzing available $\mathrm{P}$, available $\mathrm{K}$, nitrate $\left(\mathrm{NO}_{3}{ }^{-}\right)$and ammonium $\left(\mathrm{NH}_{4}{ }^{+}\right)$. Available $\mathrm{P}$ was determined by the BrayKurtz P1 method (Bray and Kurtz 1945). Available K was determined by atomic absorption spectrophotometry after extraction with a solution of $1 \mathrm{M}$ ammonium acetate, $\mathrm{pH} 7.0$ (Tan 1996). Inorganic $\mathrm{N}$ was extracted by shaking $10 \mathrm{~g}$ of soil in $30 \mathrm{~mL}$ of $1 \mathrm{M}$ $\mathrm{KCl}$ and filtered (Whatman No. 42). $\mathrm{NO}_{3}{ }^{-}$and $\mathrm{NH}_{4}{ }^{+}$ concentrations in the extracts were then determined in a Brau \& Luebe Autoanalyzer mod. 3 equipped with AA3 Digital Colorimeter following the manufacturer's instructions. Soil N:P ratios were calculated as the amount of nitrate and ammonium divided by the amount of available P. Organic matter content $(\%$
OM) of the soils was determined by weighing soil before and after heating them to $400^{\circ} \mathrm{C}$ for 8 hours.

PLFA analysis

Phospholipid fatty acids and neutral fatty acids (PLFAs and NLFAs) are constituents of lipids found in the cell membranes of living organisms and are used to estimate the biomass of individual groups of microorganisms (Olsson 1999). The biomass and composition of the soil microbial community were estimated using PLFA technique as described by Frostegård et al. (1993) in samples taken at the start of the experiment and stored at $-20{ }^{\circ} \mathrm{C}$ until analysis. Total bacterial biomass was represented by PLFAs i15:0, a15:0, 15:0, i16:0, 16:1 $\omega 9$, i17:0, a17:0,

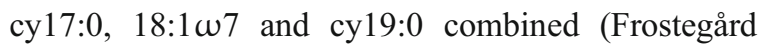
and Bååth 1996). Saprophytic fungal biomass and AM fungal biomass were represented by PLFA 18:2w6 (Frostegård and Bååth 1996) and NLFA 16:1 w5 (Olsson 1999), respectively. Amounts of PLFAs were expressed as nmol $\mathrm{g}^{-1}$ soil and as nmol $\mathrm{g}^{-1}$ organic matter.

Mycorrhizal colonization

The dried roots were soaked in tap water for half an hour before preparation for determination of $\mathrm{AM}$ colonization (Scheublin et al. 2004). Thereafter, the roots were cleared with $10 \% \mathrm{KOH}$ and fungal structures inside the roots were stained with trypan blue (Phillips and Hayman 1970). The percent root length colonized by AM fungi was estimated by a modified line intersection method (McGonigle et al. 1990; Van der Heijden 2004). We scored the presence of hyphae, vesicles and arbuscules in 75 intersections per root sample (Scheublin et al. 2004; Van der Heijden 2004).

\section{Statistical analyses}

The pots in one ex-arable habitat site were destroyed by accident. These twelve plants were left out of the analyses. One of the restoration soil samples taken for PLFA analysis was lost during analysis and was also left out of the analyses.

Data were analyzed using ANOVA with habitat and belowground environment type as fixed factors, and destination site and soil origin as random factors, 
nested within habitat and belowground environment type, respectively. Dry weight data were log-transformed prior to analysis to meet the assumptions of ANOVA. Survival of plants at day 28 was analyzed using a generalized linear mixed model with the percent surviving plants on each belowground environment type within each site as the response variable and with habitat and belowground environment type as fixed factors, and destination site as random factor, nested within habitat type. Soil characteristics of the two belowground environment types were compared with ANOVA with soil type as fixed factor.

Relations between soil chemistry, PLFAs, herbivory, and plant growth were described with linear regression, using averaged values for replicate plants grown on soil from the same origin within each of the treatments. All statistical analyses were done using $\mathrm{R}$ version 2.1.0 for Windows (R Development Core Team 2005).

\section{Results}

Soil from restoration sites contained less $\mathrm{NO}_{3}{ }^{-}$and organic matter than soil from grassland sites $\left(\mathrm{F}_{1,10}=\right.$ 5.225, $P<0.05$ and $\mathrm{F}_{1,10}=13.935, P<0.005$; Table 1). $\mathrm{K}, \mathrm{NH}_{4}{ }^{+}$and $\mathrm{P}$ content, and $\mathrm{N}: \mathrm{P}$ ratios did not differ between the soil types $(P>0.05)$. The AM fungal biomass $\left(\mathrm{F}_{1,10}=9.296, P<0.05\right)$, bacterial $\left(\mathrm{F}_{1,9}=\right.$ $6.110, P<0.05)$ and fungal biomass per gram soil $\left(\mathrm{F}_{1,9}=6.621, P<0.05\right)$ were lower in soils from restoration sites than from late-successional grasslands. The AM fungal, total bacterial and fungal biomass per gram organic matter and the fungal: bacterial ratio calculated from these data did not differ between the two soil types (all $P>0.15$ ), suggesting that the absolute differences in microbial biomass between the two soil types were the consequence of differences in organic matter content of the soils.

Survival of $C$. jacea at day 28 was higher on restoration soil than on grassland soil $\left(\mathrm{F}_{1,10}=11.122\right.$, $P<0.01)$ and higher in restoration habitats than in grassland habitat $\left(\mathrm{F}_{1,9}=4.463, P<0.05\right.$, Fig. 1$)$, which is the opposite of our expectation. Survival at day 28 was negatively correlated with organic matter content and fungal biomass of the soils (Spearman rank correlation; $\mathrm{n}=12, P<0.05$, rho $=-0.65$, and $\mathrm{n}=12$, $P<0.05$, rho $=-0.64)$.

Strong positive correlations between leaf area at day 62 and total plant and shoot weight were found,

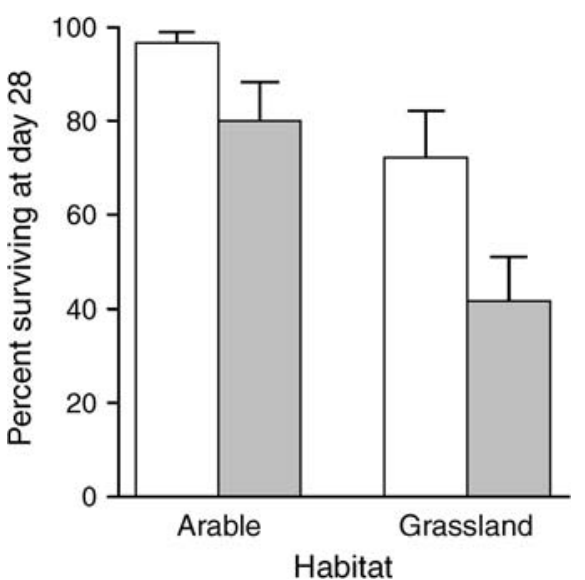

Fig. 1 Percent survival of C. jacea at day 28, grown in restoration and grassland habitats in the field experiment. Open bars indicate restoration and grey bars grassland belowground environment. Averages $+\mathrm{SE}$

indicating that leaf area was a suitable predictor of plant performance (Pearson correlations: $\mathrm{n}=84, P<$ $0.001, \mathrm{r}=0.89$ and $\mathrm{n}=84, P<0.001, \mathrm{r}=0.95)$. Despite the differences in soil nutrient content, relative growth rate between day 0 and $46(0.06 \pm 0.00)$, between day 46 and $62(0.03 \pm 0.01)$ and dry weight $(0.59 \pm$ 0.06) of $C$. jacea were not affected by belowground environment type or habitat. The relative growth rate between day 0 and 46 was positively correlated with initial N:P ratio of the soil $\left(\mathrm{n}=12, P<0.005, \mathrm{R}^{2}=0.60\right.$, Fig. 2a) and negatively correlated with initial soil $\mathrm{K}$ content $\left(\mathrm{n}=12, P<0.05, \mathrm{R}^{2}=0.42\right)$.

Herbivory as measured on surviving plants at day 28 was not affected by belowground environment type or habitat. However, herbivory at day 62 was higher on restoration soil than on grassland soil in restoration habitat, and the inverse was found in grassland habitat (Habitat by belowground environment type interaction: $\mathrm{F}_{1,81}=5.193, P<0.05$; Fig. 3). While herbivory at day 28 was not correlated with leaf area at day 28 (Spearman rank correlation, $P>$ 0.2 ), it was negatively correlated with leaf area at day 62 (Spearman rank correlation: $\mathrm{n}=85, P<0.001$, rho $=-0.46$ ), indicating that herbivore attack reduced plant performance. Herbivory at days 28 and 62 were significantly negatively correlated with total plant weight (both $P<0.05$ ).

In restoration habitat, plants growing in restoration soil were less colonized by AM fungi than plants growing in grassland soil, but in grassland habitat no difference was found in the AM colonization of plants 


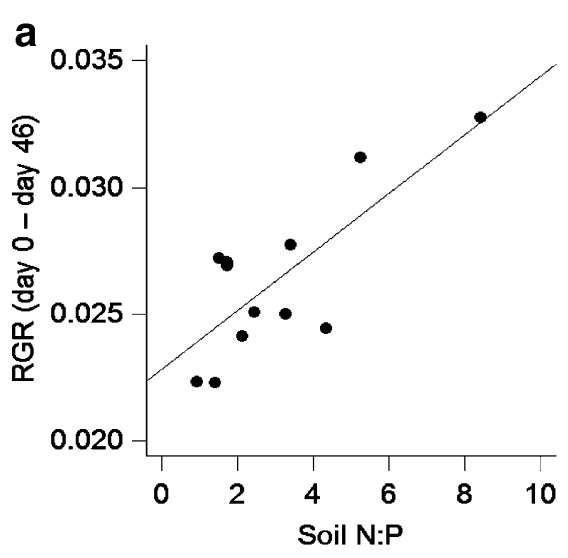

Fig. 2 Relationships between a) relative growth rate of $C$. jacea between day 0 and day $46\left(\mathrm{~mm}^{2} \mathrm{~mm}^{-2} \mathrm{~d}^{-1}\right)$ and initial $\mathrm{N}$ : $\mathrm{P}$ ratio of the soil in the field experiment and b) between

growing in restoration and grassland soil (total root colonization; $\mathrm{F}_{1,81}=6.810, P<0.05$; Fig. 4). Overall, C. jacea roots were less colonized by AM fungi in restoration habitats than in grassland habitats $\left(\mathrm{F}_{1,9}=\right.$ 16.852, $P<0.01)$. The percent colonized root length containing arbuscules did not differ between belowground environment or habitat types $(P>0.1$; Overall mean $71.52 \pm 1.59 \%$ ). The degree of mycorrhizal colonization was negatively correlated with the initial soil available-P concentration and soil water content ( $\mathrm{n}=12, P<0.05, \mathrm{R}^{2}=0.39$ and $\mathrm{n}=12, P<0.005, \mathrm{R}^{2}=$ $0.60)$. The percent colonized root length containing arbuscules was positively correlated with relative growth rate between day 46 and 62 (Pearson correlation: $\mathrm{n}=84, P<0.001, \mathrm{r}=0.39$, Fig. $2 \mathrm{~b}$ ).

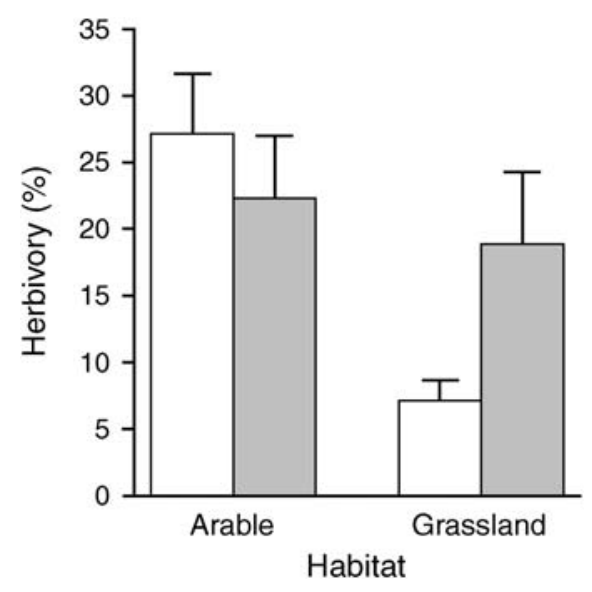

Fig. 3 Herbivory at day 62 in restoration and grassland habitats in the field experiment. Open bars indicate restoration and grey bars grassland belowground environment. Averages + SE

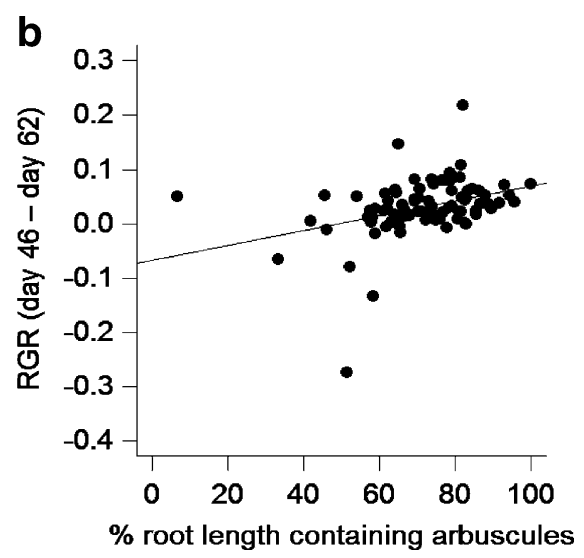

relative growth rate of $C$. jacea between day 46 and day 62 and the colonized root length containing arbuscules

\section{Discussion}

The results of the present study show that seedling survival of $C$. jacea at restoration sites can be high compared to late-successional grasslands. This contradicts the common assumption that establishment of late-successional grassland plant species on restoration sites often is low (Kleijn and Sutherland 2003). Seedling survival may depend on the degree of vegetation cover (Hutchings and Booth 1996; Kleijn 2003), but this was similar in the two habitat types in our experiment. The influence of slug herbivory on plant survival was limited as we used slug pellets, and this may lead to an underestimation of habitat effects on seedling survival (Hanley et al. 1995; Buschmann

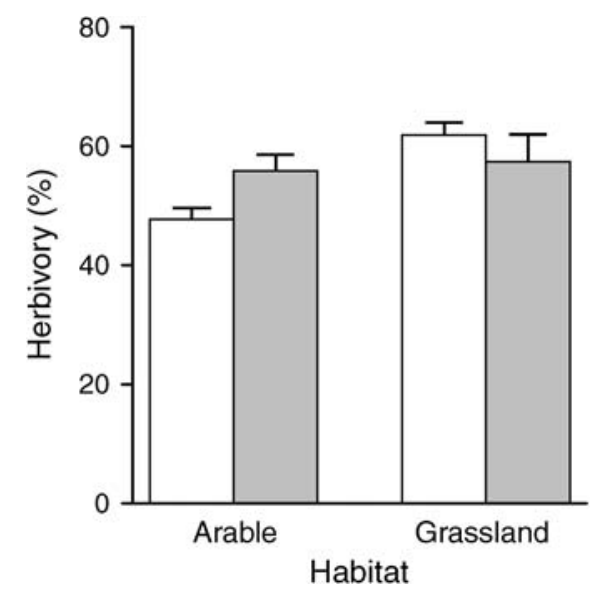

Fig. 4 Percent root length colonized by AM fungi in $C$. jacea in restoration and grassland habitats in the field experiment. Open bars indicate restoration and grey bars grassland belowground environment. Averages $+\mathrm{SE}$ 
et al. 2005). Other herbivores may also reduce survival (Edwards and Crawley 1999), but in our study the amount of herbivore damage was not different between the habitat types. It is therefore unlikely that the differences in survival rate were the result of differences in herbivory. Our study does not provide an explanation for the surprising higher seedling mortality in grassland habitat than in restoration habitat, as the survival of $C$. jacea in the two habitat types was apparently affected by parts of the aboveground environment that we did not assess.

Mycorrhizal colonization of $C$. jacea growing on restoration soil was higher in late-successional grassland habitats than in restoration habitats. The pots were used to separate the soil around the seedlings from the surrounding soil while allowing the aboveground habitat to act on the seedlings. However, although the bottoms of the pots were closed with a fine mesh, it is likely that hyphae from the surrounding soil have colonized the soil inside the pots (Fitter et al. 1998). The higher mycorrhizal colonization in late-successional grassland habitat and the interacting effect of belowground environment and habitat type on mycorrhizal colonization were therefore likely to be an effect of the surrounding soil of late-successional grasslands, rather than the aboveground environment of the habitat.

As found in earlier studies (Post and Mann 1990; Salinas-Garcia et al. 2000; Jansa et al. 2002), organic matter content and microbial biomass per gram soil were higher in the soil of the late-successional grasslands than in the soil of restoration sites. Hutchings and Booth (1996) suggested that high soil moisture content resulting from high organic matter content can be beneficial for seedling survival. The survival of seedlings in our study was negatively correlated with fungal biomass of the soils across the two soil types. Soil fungi have been shown to negatively affect the survival of early-successional plants on restoration sites (Kirkpatrick and Bazzaz 1979). Later-successional plants can be insensitive or tolerant to the pathogens of their predecessors, however, and soil-borne antagonists can thus drive succession (Van der Putten et al. 1993; De Deyn et al. 2003). The higher seedling survival on soil from restoration sites may be due to a lower abundance of pathogenic fungi in soils that were used for arable practice and where no $C$. jacea has grown for many years, and the negative feedback may be less strong in those soils than in soils from late-successional grasslands, where the soil microbial community may have been cultured by the presence of $C$. jacea. (Klironomos 2002; De Deyn et al. 2003; Kardol et al 2006; Bezemer et al. 2006; Macel et al. 2007). However, various other groups of soil organisms can also affect seedling survival, including root feeding insects and nematodes (Brown and Gange 1989; Olff et al. 2000; De Deyn et al. 2003). Further studies are required to assess the relative effect of soil fungi and other groups of soil organisms on seedling survival of $C$. jacea.

The absence of effects of the belowground environment type on plant growth rates at the beginning of the experiment probably was the consequence of the overall small difference in nutrient availability between the two belowground environment types, but the correlation between soil $\mathrm{N}: \mathrm{P}$ ratio and plant growth rate during the first weeks of the experiment show that soil nutrient availability nevertheless affected plant growth. $\mathrm{NO}_{3}{ }^{-}$availability in the present study was lower in soils from restoration sites than in soils from late-successional grasslands. This lower $\mathrm{NO}_{3}{ }^{-}$availability in restoration soils may have been due to nutrient leaching and initially higher $\mathrm{N}: \mathrm{P}$ ratios on freshly-abandoned arable land, which may lead to higher nutrient uptake rates of plants (Marrs 1993) and thus to faster reductions in $\mathrm{NO}_{3}{ }^{-}$availability. Alternatively, the greater organic matter content of the grassland soils compared to the restoration soils may lead to more mineralization, resulting in higher $\mathrm{NO}_{3}{ }^{-}$ availability in those soils.

The growth rate of $C$. jacea was positively correlated with initial $\mathrm{N}: \mathrm{P}$ ratio of the soils during the first weeks of the experiment, but later it was correlated with the fraction of the root length colonized by AM fungi that contained arbuscules, the site of phosphorus transfer from the fungus to the plant. These results suggest that the establishment of C. jacea is affected by abiotic and biotic soil factors at different stages of succession. During early succession when competition with faster-growing, earlysuccessional plant species is still moderate, a high soil $\mathrm{N}: \mathrm{P}$ ratio may promote the establishment of the seedlings, while association with AM fungi may provide competitive advantage over early-successional species that allows species to persist in the vegetation later in succession when competition is increased. The latter advantage would result from the greater benefit derived from AM fungi by later-successional species 
than by early-successional species (Janos 1980). The level of AM fungal colonization of plant roots and its effect on plant growth may vary depending on the composition and abundance of the AM fungal species (Van der Heijden et al. 1998) and the available nutrients (Reynolds et al. 2006). The significant correlations between abiotic soil characteristics, such as water content, $\mathrm{N}: \mathrm{P}$ ratio, $\mathrm{P}$ and $\mathrm{K}$ concentrations, and the fraction of colonized root length containing arbuscules across aboveground and belowground environment types confirm the results of previous studies (Sanders and Sheikh 1983; Smith and Read 1997; Blanke et al. 2005). Hence, the results suggest that plants are more likely to encounter circumstances that promote AM fungal colonization at sites with such abiotic soil conditions and have higher establishment rates. Our investigations largely focused on AM fungi, which generally have a positive influence on plant growth, but other groups of soil organism can either positively or negatively impact plant performance (Brown and Gange 1989; Olff et al. 2000; Klironomos 2002; De Deyn et al. 2003; Kardol et al. 2006). The overall effect of the belowground environment clearly depends on the combined impact of the various groups of organisms (Bever et al. 1997).

Our study is one of the first to disentangle the relative importance of aboveground and belowground environment for the survival and growth of a latesuccessional grassland plant species by reciprocally transplanting soil among multiple sites of two contrasting habitat types. Although we cannot relate our findings to specific factors, we found that the impact of the aboveground environment type was greater than the impact of belowground environment type on survival of $C$. jacea. In contrast to other studies (e.g. Kleijn 2003), relative growth rate of the surviving plants was most affected by the belowground environment. Our results indicate that AM colonization may play an important role in successful establishment of $C$. jacea in grasslands. In line with previous studies (Sanders and Sheikh 1983; Smith and Read 1997; Blanke et al. 2005), our results also indicate that soil water content, $\mathrm{N}: \mathrm{P}$ ratio, $\mathrm{P}$ and $\mathrm{K}$ concentrations are important characteristics that promote AM colonization. Hence, these soil factors may be indicative of suitable conditions for establishment of $C$. jacea and eventually for other late-successional plant species. We therefore propose that biotic and abiotic characteristics of the belowground environment should be considered in the selection of sites for grassland restoration.

Acknowledgements We thank Stefan Gross and Heather Kirk for technical help, and Marius Grecu for analyzing root colonization. We are grateful to José M. Igual for generously offering to do the soil chemical analyses, and to Katarina Hedlund for help with the PLFA analyses. Marcel van der Heijden commented on a previous version of the manuscript. Further constructive comments by two reviewers and the section editor Wim van der Putten are greatly acknowledged and helped to improve the manuscript. This work was supported by the Swiss Federal Office for Education and Science (Project 01.0086) to join the 'TLinks' project funded by the European Commission within the Framework V Energy, Environment and Sustainable Development Programme (EVK2-CT-2001-00123 to HMS and US).

\section{References}

Bardgett RD, McAlister E (1999) The measurement of soil fungal:bacterial biomass ratios as an indicator of ecosystem self-regulation in temperate meadow grasslands. Biol. Fert. Soils 29:282-290

Bever J, Westover K, Antonovics J (1997) Incorporating the soil community into plant population dynamics: the utility of the feedback approach. J. Ecol. 85:561-573

Bezemer TM, Lawson CS, Hedlund K et al (2006) Plant species and functional group effects on abiotic and microbial soil properties and plant-soil feedback responses in two grasslands. Journal of Ecology 94:893-904

Blanke V, Renker C, Wagner M et al (2005) Nitrogen supply affects arbuscular mycorrhizal colonization of Artemisia vulgaris in a phosphate-polluted field site. New Phyt. 166:981-992

Bray RH, Kurtz LT (1945) Determination of total, organic, and available forms of phosphorus in soils. Soil Sci. 59:39-45

Bosshard A (1999) Renaturierung artenreicher Wiesen auf nährstoffreichen Böden. Dissertationes Botanicae 303. J Cramer, Berlin, Germany

Brown VK, Gange AC (1989) Differential effects of above- and below-ground insect herbivory during early plant succession. Oikos 54:67-76

Buschmann H, Keller M, Porret N et al (2005) The effect of slug grazing on vegetation development and plant species diversity in an experimental grassland. Func. Ecol. 19:291-298

De Deyn GB, Raaijmakers CE, Zoomer HR et al (2003) Soil invertebrate fauna enhances grassland succession and diversity. Nature 422:711-713

Edwards GR, Crawley MJ (1999) Herbivores, seed banks and seedling recruitment in mesic grassland. J. Ecol. 87:423435

Ellenberg H (1974) Zeigerwerte der Gefäßflanzen Mitteleuropas. Goltze, Göttingen, Germany

Fitter AH, Graves JD, Watkins NK et al (1998) Carbon transfer between plants and its control in networks of arbuscular mycorrhizas. Funct. Ecol. 12:406-412 
Frostegård Å, Bååth E, Tunlid A (1993) Shifts in the structure of soil microbial communities in limed forests as revealed by phospholipid fatty acid analysis. Soil Biol. Bioch. 25:723-730

Frostegård A, Bååth E (1996) The use of phospholipid fatty acid analysis to estimate bacterial and fungal biomass in soil. Biol. Fert. Soils 22:59-65

Gange AC, West HM (1994) Interactions between arbuscular mycorrhizal fungi and foliar feeding insects in Plantago lanceolata L. New Phyt. 128:79-87

Gange AC, Bower E, Brown VK (2002) Differential effects of insect herbivory on arbuscular mycorrhizal colonization. Oecologia 131:103-112

Hanley ME, Fenner M, Edwards PJ (1995) An experimental study of the effects of mollusc grazing on seedling recruitment and survival in grassland. J. Ecol. 83:621-627

Hansson M, Fogelfors H (1998) Management of permanent setaside on arable land in Sweden. J. Appl. Ecol. 35:758-771

Hutchings M, Booth K (1996) Studies on the feasibility of recreating chalk grassland vegetation on ex-arable land. II. Germination and early survivorship under different management regimes. J. Appl. Ecol. 33:1182-1190

Janos DP (1980) Mycorrhizae influence tropical succession. Tropical Succession:56-64

Jansa J, Mozafar A, Anken T et al (2002) Diversity and structure of AMF communities as affected by tillage in a temperate soil. Mycorrhiza 12:225-234

Kardol P, Bezemer TM, van der Putten WH (2006) Temporal variation in plant-soil feedback controls succession. Ecol. Lett. 9:1080-1088

Kardol P, Bezemer TM, Van der Putten WH (2008) Soil Organism and Plant Introductions in Restoration of Species-Rich Grassland Communities. Restoration Ecology (in press)

Kindscher K, Tieszen LL (1998) Floristic and organic matter changes after five and thrirty-five years of native tallgrass prairie restoration. Rest. Ecol. 6:181-196

Kirkpatrick BL, Bazzaz FA (1979) Influence of certain fungi on seed germination and seedling survival of four colonizing annuals. J. Appl. Ecol. 16:515-257

Kleijn D (2003) Can establishment characteristics explain the poor colonization success of late successional grassland species on ex-arable land? Rest. Ecol. 11:131-138

Kleijn D, Sutherland WJ (2003) How effective are European agri-environment schemes in conserving and promoting biodiversity? J. Appl. Ecol. 40:947-969

Klironomos JN (2002) Feedback with soil biota contributes to plant rarity and invasiveness in communities. Nature 417:67-70

Macel M, Lawson CS, Mortimer SR et al (2007) Climate versus soil factors in local adaptation of two common plant species. Ecology 88:424-433

Marrs RH (1993) Soil fertility and nature conservation in Europe: Theoretical considerations and practical management solutions. Adv. Ecol. Res. 24:241-300

McGonigle TP, Miller MH, Evans DG et al (1990) A new method which gives an objective measure of colonization of roots by vesicular-arbuscular mycorrhizal fungi. New Phyt. 115:495-501

McLendon T, Redente EF (1992) Effects of nitrogen limitation on species replacement dynamics during early secondary succession on a semiarid sagebrush site. Oecologia 91:312-317

Olff H, Hoorens B, de Goede RGM et al (2000) Small-scale shifting mosaics of two dominant grassland species: the possible role of soil-borne pathogens. Oecologia 125:45-54
Olsson PA (1999) Signature fatty acids provide tools for determination of the distribution and interactions of mycorrhizal fungi in soil. FEMS Microb. Ecol. 29:303-310

Phillips JM, Hayman DS (1970) Improved procedures for clearing roots and staining parasitic and vesicular-arbuscular mycorrhizal fungi for rapid assessment of infection. Trans. Brit. Mycol. Soc. 55:158-161

Post WM, Mann LK (1990) Changes in soil organic carbon and nitrogen as a result of cultivation. In: Bouwman AF (ed) Soils and the Greenhouse effect. New York, USA: John Wiley and Sons Ltd., pp 401-406

R Development Core Team (2005) R: A language and environment for statistical computing. R Foundation for Statistical Computing, Vienna, Austria

Read DJ (2002) Towards ecological relevance-Progress and pitfalls in the path towards an understanding of mycorrhizal functions in Nature. In: Van der Heijden MGA, Sanders IR (eds) Mycorrhizal Ecology. Springer Verlag, Berlin, Germany

Reynolds HL, Vogelsang KM, Hartley AE et al (2006) Variable responses of old-field perennials to arbuscular mycorrhizal fungi and phosphorus source. Oecologia 147:348-358

Salinas-Garcia JR, Velazquez-Garcia JdJ, Rosales-Robles E et al (2000) Mid-term effects of tillage on microbial biomass and nutrient distribution in vertisols and andisols under rain-fed corn production. Terra 18:349-359

Sanders FE, Sheikh NA (1983) The development of vesiculararbuscular mycorrhizal infection in plant root systems. Plant Soil 71:223-246

Schädler M, Jung G, Brandl R, Auge H (2004) Secondary succession is influenced by belowground insect herbivory on a productive site. Oecologia 138:242-252

Scheublin TR, Ridgway KP, Young JPW et al (2004) Nonlegumes, legumes, and and root nodules harbor different arbuscular mycorrhizal fungal communities. Appl. Env. Microbiol. 70:6240-6246

Smith SE, Read DJ (1997) Mycorrhizal symbiosis 2nd Ed. Academic Press, London, UK, pp 379-408

Tan KH (1996) Soil Sampling, Preparation and Analysis. Dekker, New York, USA

Tilman D (1993) Species richness of experimental productivity gradients: how important is colonization limitation? Ecology 74:2179-2191

Van der Heijden MGA (2004) Arbuscular mycorrhizal fungi as support systems for seedling establishment in grassland. Ecology Letters 7:293-303

Van der Heijden MGA, Klironomos JN, Ursic M et al (1998) Mycorrhizal fungal diversity determines plant biodiversity, ecosystem variability and productivity. Nature 396:69-72

Van der Putten WH, Van Dijk CA, Peters BAM (1993) Plantspecific soil-borne diseases contribute to succession in foredune vegetation. Nature 362:53-56

Walker KJ, Stevens PA, Stevens DP et al (2004) The restoration and re-creation of species-rich lowland grassland on land formerly managed for intensive agriculture in the UK. Biological Conservation 119:1-18

Wardle DE (2002) Communities and Ecosystems. Princeton university press, Princeton, USA

Wardle DE, Williamson WM, Yeates GW et al (2005) Trickledown effects of aboveground trophic cascades on the soil food web. Oikos 111:348-358 